\title{
Involvement of a Quinoprotein Alcohol Dehydrogenase and an NAD-dependent Aldehyde Dehydrogenase in 2-Chloroethanol Metabolism in Xanthobacter autotrophicus GJ10
}

\author{
By DICK B. JANSSEN, * SYTZE KEUNING AND BERNARD WITHOLT \\ Groningen Biotechnology Centre, University of Groningen, Nijenborgh 16, 9747 AG Groningen, \\ The Netherlands
}

(Received 1 June 1986; revised 25 July 1986)

\begin{abstract}
An inducible methanol dehydrogenase showing high activity with 2-chloroethanol was purified from 2-chloroethanol-grown cells of the 1,2-dichloroethane utilizing bacterium Xanthobacter autotrophicus GJ10. The enzyme consisted of a $60 \mathrm{kDa}$ polypeptide that was associated with a $10 \mathrm{kDa}$ polypeptide and contained pyrrolo-quinoline quinone (PQQ) as a prosthetic group. Chloroethanol-grown cells of strain GJ10 also contained an inducible NAD-dependent chloroacetaldehyde dehydrogenase. Its involvement in the metabolism of 2-chloroethanol was inferred from its absence in a 2-chloroethanol non-utilizing mutant. Three different isolates of $X$. autotrophicus that do not utilize 2-chloroethanol for growth produced chloroethanol dehydrogenase and chloroacetaldehyde dehydrogenase activities at similar levels as strain GJ10. It is concluded that both dehydrogenases are involved in the metabolism of natural compounds and due to their broad substrate specificity fortuitously also play a role in the metabolism of the xenobiotic compounds 1,2-dichloroethane and 2-chloroethanol.
\end{abstract}

\section{INTRODUCTION}

Xanthobacter autotrophicus $\mathrm{GJ} 10$ is a nitrogen-fixing hydrogen bacterium that is able to utilize 1,2-dichloroethane or 2-chloroethanol as a sole carbon and energy source (Janssen et al., 1984, 1985). The organism constitutively produces two dehalogenases, one specific for 1,2dichloroethane and related haloalkanes (Keuning et al., 1985), and one specific for halogenated carboxylic acids. It was proposed that 1,2-dichloroethane is degraded via 2-chloroethanol, chloroacetaldehyde and chloroacetic acid to glycolate. During growth on 1,2-dichloroethane or methanol, $X$. autotrophicus GJ10 produced both methanol dehydrogenase and 2-chloroethanol dehydrogenase activities. This simultaneous induction raised the supposition that the activities are related to a single protein (Janssen et al., 1985). Conversion of 2-chloroethanol by purified methanol dehydrogenase was observed by Anthony \& Zatman (1967) for the enzyme of Pseudomonas M27 and by Beardsmore-Gray et al. (1983) for the enzyme of Methylophilus methylotrophus.

Further metabolism by the above route would require the presence of chloroacetaldehyde dehydrogenase. This activity has not yet been demonstrated in $X$. autotrophicus GJ10, but an NAD-dependent chloroacetaldehyde dehydrogenase was described in an unidentified 1,2dichloroethane utilizing bacterium (Stucki et al., 1983).

In this paper, we describe the regulation and properties of a quinoprotein alcohol dehydrogenase that is also involved in the metabolism of methanol and 2-chloroethanol. Furthermore, the characteristics of a 2-chloroethanol non-utilizing mutant demonstrate the involvement of an inducible NAD-dependent aldehyde dehydrogenase in ethanol and 2chloroethanol metabolism.

Abbreviations: PQQ, pyrrolo-quinoline quinone; MMV, mineral salts-vitamins medium; PMS, phenazine methosulphate; PPM, pyrophosphate-methanol buffer. 


\section{METHODS}

Organism and growth conditions. All organisms used in this study were strains of Xanthobacter autotrophicus (Wiegel et al., 1978). The characteristics of strain GJ10 were described by Janssen et al. (1984, 1985). Strain GJ10M41 is a 1,2-dichloroethane non-utilizing mutant that was isolated as described below. Strain GZ29 and strain 7C (the type strain of this species; Wiegel et al., 1978; Tunail \& Schlegel, 1974) were kindly donated by Professor H. G. Schlegel. Strain XD was isolated as a methanol utilizing organism and was a gift from Dr L. Dijkhuizen.

Cells were grown aerobically at $30^{\circ} \mathrm{C}$ in a mineral salts medium (MMV) containing $\left(1^{-1}\right) 5 \cdot 37 \mathrm{~g} \mathrm{Na}_{2} \mathrm{H}_{-} \mathrm{PO}_{4}$.

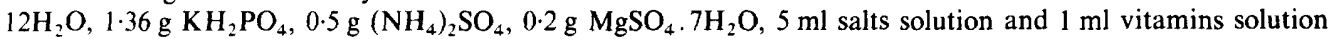
(Janssen et al., 1984). Carbon sources were added as indicated at $10 \mathrm{~mm}$. For the isolation of 2-chloroethanol dehydrogenase, cells were grown on $20 \mathrm{~mm}$-2-chloroethanol in a 101 fermenter (Braun Biostat E) at pH 7.0 and $70 \%$ oxygen saturation.

Preparation of crude extracts. Cells were collected by centrifugation, washed with $10 \mathrm{~mm}-\mathrm{Tris} / \mathrm{H}_{2} \mathrm{SO}_{4}$ buffer, $\mathrm{pH} 7.5$ (Tris buffer), and resuspended in Tris buffer $\left.[2 \mathrm{ml} \text { ( } \mathrm{g} \text { wet } \mathrm{wt})^{-1}\right]$. The cells were disrupted by sonication [10 $\mathrm{s}$ (ml suspension) ${ }^{-1}$ at $60 \mathrm{~W}$ output in an Ultrasonics W-375 sonicator]. After centrifugation ( $30 \mathrm{~min}, 45000 \mathrm{~g}$ ), a crude extract was obtained and used for enzyme assays within $6 \mathrm{~h}$.

Enzyme assays. Alcohol dehydrogenase activities were determined at $30^{\circ} \mathrm{C}$ in a biological oxygen monitor equipped with a Clark-type oxygen electrode. Incubation mixtures contained (in a final volume of $6 \mathrm{ml}$ ) $60 \mathrm{mM}$ sodium pyrophosphate buffer ( $\mathrm{pH} 9 \cdot 0$ ), $23 \mathrm{mM}-\mathrm{NH}_{4} \mathrm{Cl}, 4 \mathrm{~mm}$-substrate and a suitable amount of enzyme in $1 \mathrm{ml}$ Tris buffer. The reaction was started by the addition of $0.2 \mathrm{ml} 30 \mathrm{~mm}$-phenazine methosulphate (PMS), and oxygen consumption was followed. One unit of activity $(\mathrm{U})$ is defined as that catalysing an oxygen consumption

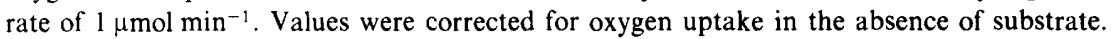

Chloroacetaldehyde dehydrogenase activities were assayed spectrophotometrically at $30^{\circ} \mathrm{C}$ by following the reduction of NAD at $334 \mathrm{~nm}$. Reaction mixtures contained (in a final volume of $1 \mathrm{ml}$ ) $100 \mathrm{~mm}$-sodium pyrophosphate, pH 8.75, $1 \mathrm{~mm}$-NAD, $1 \mathrm{~mm}$ dithiothreitol, $10 \mathrm{~mm}-\beta$-mercaptoethanol, $5 \mathrm{~mm}$-chloroacetaldehyde, and a suitable amount of enzyme in $0.1 \mathrm{ml}$ Tris buffer containing $1 \mathrm{~mm}$-dithiothreitol and $10 \mathrm{~mm}$ $\beta$-mercaptoethanol. The latter two compounds were added to the crude extracts immediately after preparation, since this was found to stabilize enzyme activity. The reaction was started by the addition of substrate. One unit is defined as the activity catalysing the formation of $1 \mu \mathrm{mol}$ NADH $\min ^{-1}$.

1,2-Dichloroethane dehalogenase and chloroacetic acid dehalogenase were assayed by following chloride production as described by Janssen et al. (1985) and Keuning et al. (1985). Protein concentrations were determined by the Lowry method using bovine serum albumin as the standard.

Purification of 2-chloroethanol dehydrogenase. The enzyme was purified at $4{ }^{\circ} \mathrm{C}$ from 2-chloroethanol-grown cells (13 g dry wt) principally according to the procedure described by Schär et al. (1985) for the isolation of methanol dehydrogenase from Hyphomicrobium MS223. Briefly, crude extract was prepared in $10 \mathrm{~mm}$-sodium pyrophosphate buffer, pH 9.0, containing $10 \mathrm{~mm}$-methanol (PPM buffer), and subsequently fractionated by stepwise addition of solid ammonium sulphate. The $55-80 \%$ saturation precipitate was dissolved in $10 \mathrm{ml}$ PPM buffer, dialysed overnight against 21 PPM buffer, and then applied to a DEAE-cellulose column (Whatman DE52, $2 \times 30 \mathrm{~cm}$ ) that had been previously equilibrated with PPM buffer. Activity passed through the column without retention and was concentrated by precipitation with ammonium sulphate $(80 \%$ saturation). The enzyme was further purified by Sephacryl S-300 chromatography. Activity was eluted from the column $(2 \times 100 \mathrm{~cm})$ with PPM buffer, concentrated by ammonium sulphate precipitation, and applied to a Sephadex G-100 column $(2 \times 80 \mathrm{~cm})$. After elution with PPM buffer, fractions containing the highest activity were pooled and stored frozen at $-20^{\circ} \mathrm{C}$ until used.

Molecular mass determinations. The subunit size of the protein was determined by SDS-PAGE on $10 \%$ or $15 \%$ (w/v) polyacrylamide according to the method of Laemmli (1970). The following proteins were used for calibration: phosphorylase B $(92 \mathrm{kDa})$, bovine serum albumin $(68 \mathrm{kDa})$, ovalbumin $(45 \mathrm{kDa})$, aldolase (40 kDa), chymotrypsinogen $(25 \mathrm{kDa})$ and cytochrome $c(12.4 \mathrm{kDa})$. The gels were stained with Coomassie brilliant blue.

The molecular mass of the native enzyme was estimated using a Sephadex G-100 column that was run as described above. The column was calibrated with alcohol dehydrogenase ( $145 \mathrm{kDa})$, bovine serum albumin, ovalbumin, trypsin inhibitor $(20.1 \mathrm{kDa})$ and cytochrome $c$. All calibration proteins were obtained from Boehringer.

Cross-linking with the bifunctional reagent $N, N$-dimethylsuberimidate $\left(0 \cdot 5-5 \mathrm{mg} \mathrm{ml}^{-1}\right.$ in $0 \cdot 2 \mathrm{M}$-triethanolamine buffer, $\mathrm{pH} \mathrm{8.5)}$ was done for $16 \mathrm{~h}$ at $30^{\circ} \mathrm{C}$, using an enzyme solution $\left(1 \mathrm{mg} \mathrm{ml}^{-1}\right)$ that has been previously dialysed overnight against triethanolamine buffer.

Isolation of 1,2-dichloroethane non-utilizing mutants. Mutants of strain GJ10 that do not utilize 1,2-dichloroethane for growth were obtained after nitrite mutagenesis and glycine contraselection, using a procedure adopted from Wilke \& Schlegel (1979). Mutants were contraselected for $20 \mathrm{~h}$ in MMV medium containing $2 \%$ (w/v) L-glycine and $5 \mathrm{~mm}-1,2$-dichloroethane; surviving cells were grown in MMV medium containing $10 \mathrm{~mm}$-glycolic acid for $20 \mathrm{~h}$. After two enrichment cycles, cells were plated on MMV medium with glycolate as carbon source. Mutants were identified by replica plating, purified and stored on nutrient agar plates. 
Table 1. Regulation of 2-chloroethanol dehydrogenase and chloroacetaldehyde dehydrogenase formation

Crude extracts were prepared from cells grown with different carbon sources and enzyme activities were determined as described in Methods. Values represent means from two or three experiments.

\begin{tabular}{lccc}
\cline { 2 - 4 } Growth substrate & $\begin{array}{c}\text { Methanol } \\
\text { dehydrogenase }\end{array}$ & $\begin{array}{c}\text { 2-Chloroethanol } \\
\text { dehydrogenase }\end{array}$ & $\begin{array}{c}\text { Chloroacetaldehyde } \\
\text { dehydrogenase }\end{array}$ \\
1,2-Dichloroethane & 520 & 480 & 109 \\
2-Chloroethanol & 440 & 415 & 68 \\
Citrate & $<10$ & $<10$ & $<10$ \\
Methanol & 508 & 515 & 15 \\
Ethanol & 295 & 295 & 200 \\
Glycolate & 404 & 438 & 13
\end{tabular}

Table 2. Purification of 2-chloroethanol dehydrogenase

The enzyme was purified from $13 \mathrm{~g}$ (dry wt) of 2-chloroethanol-grown cells, according to the procedure given in Methods. After each step, methanol dehydrogenase and 2-chloroethanol dehydrogenase activities were determined in the pooled fractions.

\begin{tabular}{|c|c|c|c|c|c|}
\hline \multirow[b]{2}{*}{ Step } & \multirow{2}{*}{$\begin{array}{l}\text { Protein } \\
\text { (mg) }\end{array}$} & \multicolumn{2}{|c|}{$\begin{array}{l}\text { Dehydrogenase activity } \\
{\left[\mathrm{U}(\mathrm{mg} \text { protein })^{-1}\right]}\end{array}$} & \multirow[b]{2}{*}{$\begin{array}{l}\text { Purification } \\
\text { factor }\end{array}$} & \multirow[b]{2}{*}{$\begin{array}{l}\text { Yield } \\
(\%)\end{array}$} \\
\hline & & Methanol & 2-Chloroethanol & & \\
\hline Crude extract & 6200 & $0 \cdot 44$ & 0.4 & 1 & 100 \\
\hline$\left(\mathrm{NH}_{4}\right)_{2} \mathrm{SO}_{4}$ precipitation & 646 & $2 \cdot 8$ & $2 \cdot 6$ & 6.5 & 69 \\
\hline DEAE-cellulose & 101 & $12 \cdot 9$ & $12 \cdot 0$ & 30 & 52 \\
\hline Sephacryl S-300 & 40 & $14 \cdot 4$ & $13 \cdot 0$ & $32 \cdot 5$ & 22 \\
\hline Sephadex G-100 & 19 & $17 \cdot 0$ & $15 \cdot 5$ & 39 & 12 \\
\hline
\end{tabular}

\section{RESULTS}

\section{Identification and regulation of enzymes involved in 2-chloroethanol metabolism}

Crude extracts of 2-chloroethanol-grown cells of $X$. autotrophicus GJ10 were found to contain $415 \mathrm{mU}$ (mg protein) $)^{-1}$ of PMS-linked 2-chloroethanol dehydrogenase activity. Without addition of ammonia to the assay mixture or with Tris $/ \mathrm{H}_{2} \mathrm{SO}_{4}$ buffer instead of sodium pyrophosphate buffer, a value of $240 \mathrm{mU}$ (mg protein) ${ }^{-1}$ was obtained. No activity could be detected when PMS was omitted from the incubation mixture or when it was replaced by $1 \mathrm{~mm}$ NAD or NADP.

With 2-chloroacetaldehyde as the substrate, crude extracts of 2-chloroethanol-grown cells reduced NAD at a rate of $68 \mathrm{mU}$ (mg protein $)^{-1}$, under the standard assay conditions. No chloroacetaldehyde dehydrogenase activity could be detected with NADP or PMS as the electron acceptor. With Tris $/ \mathrm{H}_{2} \mathrm{SO}_{4}$ buffer instead of sodium pyrophosphate buffer in the incubation mixture, an activity of $35 \mathrm{mU}$ (mg protein $)^{-1}$ was obtained. The enzyme was stabilized in crude extracts by addition of reducing agents, with less than $20 \%$ inactivation occurring during storage at $4{ }^{\circ} \mathrm{C}$ for $20 \mathrm{~h}$. The optimum pH for activity was 8.7 .

The two dehydrogenases were inducible enzymes (Table 1). During growth with 2chloroethanol, 1,2-dichloroethane or ethanol, the formation of both chloroethanol dehydrogenase and chloroacetaldehyde dehydrogenase was derepressed. Growth with methanol or glycolate only derepressed 2-chloroethanol dehydrogenase, showing that the enzymes are not coordinately regulated.

\section{Purification and characterization of 2-chloroethanol dehydrogenase}

2-Chloroethanol dehydrogenase was purified from crude extracts of cells grown with 2chloroethanol as carbon source; the purification scheme is summarized in Table 2 . The enzyme was purified 39-fold, with an overall yield of $12 \%$, which implies that 2-chloroethanol 


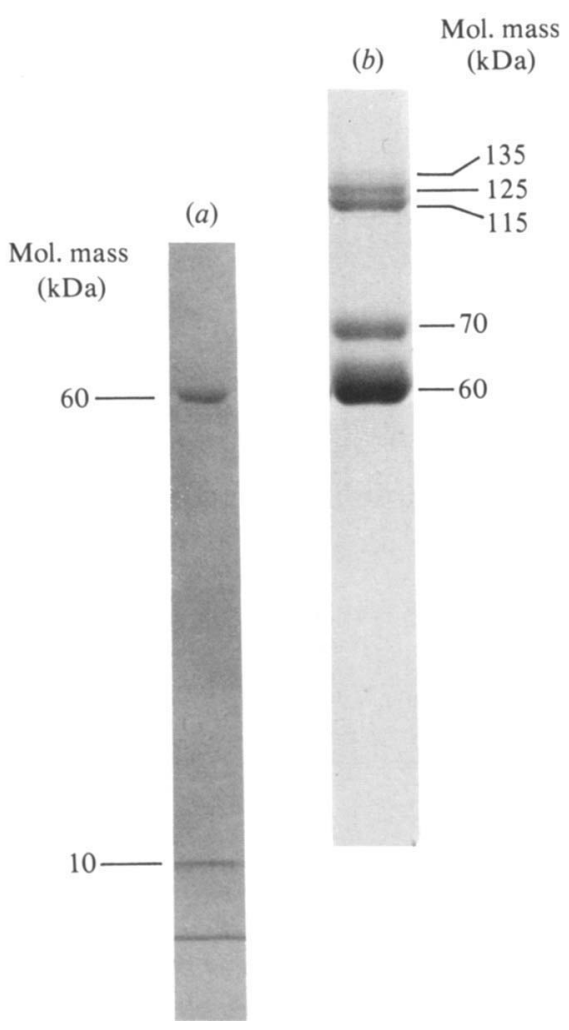

Fig. 1. SDS-PAGE of quinoprotein alcohol dehydrogenase from $X$. autotrophicus GJ10. The molecular masses of the relevant bands are indicated. (a) Electrophoresis of purified enzyme on a $15 \%$ polyacrylamide gel. (b) Electrophoresis of purified enzyme on a $10 \%$ polyacrylamide gel after crosslinking with $N, N$-dimethylsuberimidate.

dehydrogenase accounts for at least $2.5 \%$ of the total cellular protein. Methanol dehydrogenase activity copurified with 2-chloroethanol dehydrogenase: the ratio of the activities measured with 2-chloroethanol and with methanol as substrate was constant at 0.9 throughout the purification procedure.

SDS-PAGE of the purified enzyme gave two polypeptide bands. Calibration indicated that these had molecular masses of $60 \mathrm{kDa}$ and $10 \mathrm{kDa}$, showing that a small polypeptide remained associated with the $60 \mathrm{kDa}$ protein during the two gel filtration steps. Gel filtration on Sephadex G-100 indicated that the molecular mass of the purified native dehydrogenase was $66 \mathrm{kDa}$. However, after dialysis of the purified enzyme against $10 \mathrm{~mm}-\mathrm{Tris} / \mathrm{H}_{2} \mathrm{SO}_{4}, \mathrm{pH} 7.5$, and rechromatography on Sephadex G-100, a molecular mass of $120 \mathrm{kDa}$ was obtained. This value

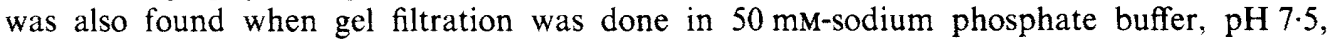
indicating that the subunit composition of the enzyme strongly depends on the experimental conditions.

Dimers of 2-chloroethanol dehydrogenase were also found after treatment with the bifunctional coupling reagent dimethylsuberimidate (Fig. 1). The appearance of a protein band at $70 \mathrm{kDa}$ suggests that the reagent couples the $10 \mathrm{kDa}$ polypeptide to the dehydrogenase. It is reasonable to assume that the bands with molecular masses of $115 \mathrm{kDa}, 125 \mathrm{kDa}$ and $135 \mathrm{kDa}$ are generated, respectively, by a dehydrogenase dimer, a dimer with one $10 \mathrm{kDa}$ protein, and a dimer coupled to two $10 \mathrm{kDa}$ proteins.

The absorption spectrum of the purified 2-chloroethanol dehydrogenase showed a maximum at $345 \mathrm{~nm}$ with a shoulder at $410 \mathrm{~nm}$, which is characteristic of alcohol dehydrogenases containing PQQ as a prosthetic group (Anthony, 1982; Duine \& Frank, 1981 a). 
Table 3. Enzyme activities in X. autotrophicus GJ10 and in the mutant GJ10M4I

Crude extracts were prepared from cells of strain GJ10 and the 1,2-dichloroethane non-utilizing mutant GJ10M41 after growth with different carbon sources. All values represent means from two or three experiments. NT, Not tested.

\begin{tabular}{llcccc} 
Strain & \multicolumn{1}{c}{ Growth medium } & $\begin{array}{c}\text { 1,2-Dichloro- } \\
\text { ethane } \\
\text { dehalogenase }\end{array}$ & $\begin{array}{c}\text { 2-Chloro- } \\
\text { ethanol } \\
\text { dehydrogenase }\end{array}$ & $\begin{array}{c}\text { Chloro- } \\
\text { acetaldehyde } \\
\text { dehydrogenase }\end{array}$ & $\begin{array}{c}\text { Chloro- } \\
\text { acetate } \\
\text { dehalogenase }\end{array}$ \\
GJ10 & Citrate +2-chloroethanol & 185 & 94 & 90 & 216 \\
GJ10M41 & Citrate+2-chloroethanol & 188 & $<5$ & $<10$ & 303 \\
GJ10M41 & Methanol & NT & 259 & $<10$ & NT \\
GJ10M41 & Ethanol & 120 & 248 & $<10$ & 1740 \\
GJ10M41 & Glycolate & NT & 214 & $<10$ & NT
\end{tabular}

Dehydrogenase activity with 2-chloroethanol or methanol as the substrate was maximal at $\mathrm{pH} 9 \cdot 0-9 \cdot 4$ and a temperature of $40^{\circ} \mathrm{C}$. At temperatures of $50{ }^{\circ} \mathrm{C}$ or above, the enzyme was rapidly inactivated. The purified dehydrogenase catalysed the oxidation of a wide range of primary alcohols. 1-Propanol, 1-butanol, 1-octanol, 2-chloroethanol, 2-bromoethanol and formaldehyde were oxidized at $80-90 \%$ of the rate found with methanol. The highest rate $(120 \%)$ was found with ethanol, while 1-pentanol $(41 \%)$ and 3-propenol $(72 \%)$ were also substrates for the enzyme. No activity was found with 2-propanol, 2-butanol, isobutylalcohol, acetaldehyde, propionaldehyde, butyraldehyde or chloroacetaldehyde. Glycolate, which induced the formation of the enzyme, was not a substrate.

\section{Characterization of a 1,2-dichloroethane non-utilizing mutant}

Enrichment for 1,2-dichloroethane non-utilizing mutants yielded strain GJ10M41 which was unable to grow with 1,2-dichloroethane or 2-chloroethanol as sole carbon source. Mutant GJ10M41 was able to grow on glycolate, methanol or citrate, but ethanol was a poor carbon source, giving a doubling time of $40 \mathrm{~h}$, compared to $5.9 \mathrm{~h}$ for the wild type. Doubling times with methanol were 5.4 and $5.2 \mathrm{~h}$ for strains GJ10 and GJ10M41, respectively. In crude extracts of strain GJ10M41, prepared from cells grown on glycolate, methanol or ethanol, no chloroacetaldehyde dehydrogenase activity could be detected, while dehalogenase and 2chloroethanol dehydrogenase levels were normal (Table 3). This suggests that the primary defect in strain GJ10M41 is a lack of chloroacetaldehyde dehydrogenase activity. The mutant was found to lack both 2-chloroethanol dehydrogenase and chloroacetaldehyde dehydrogenase when grown on a medium containing citrate and 2-chloroethanol, which may be caused by inactivation of the alcohol dehydrogenase by accumulating chloroacetaldehyde, or impairment of its synthesis by mutational or regulatory events.

The loss of 2-chloroacetaldehyde dehydrogenase activity in mutant GJ10M41 had another secondary effect: toxicity of 2-chloroethanol. In batch cultures, the doubling time of strain GJ10M41 with citrate plus 2-chloroethanol as carbon sources was $45 \mathrm{~h}$, compared to $6 \mathrm{~h}$ for GJ 10M4l with citrate alone and $6.5 \mathrm{~h}$ for the wild-type with both citrate and 2-chloroethanol in the medium. Addition of 2-chloroethanol to cells growing with methanol as carbon source caused a rapid inhibition of growth in strain GJ10M41 but not in strain GJ10 (Fig. 2). Thus, the inability to convert chloroacetaldehyde gives 2-chloroethanol the characteristics of a toxic substrate for this mutant.

\section{Enzymes of 1,2-dichloroethane metabolism in other strains of Xanthobacter}

The ability to produce dehydrogenases that are active with chlorinated substrates could be either specific for strain GJ10, or it could be a general characteristic of Xanthobacter. This was investigated by comparing strain GJ10 with three different strains that do not utilize 1,2dichloroethane or 2-chloroethanol for growth, but can grow on glycolate. During growth on 


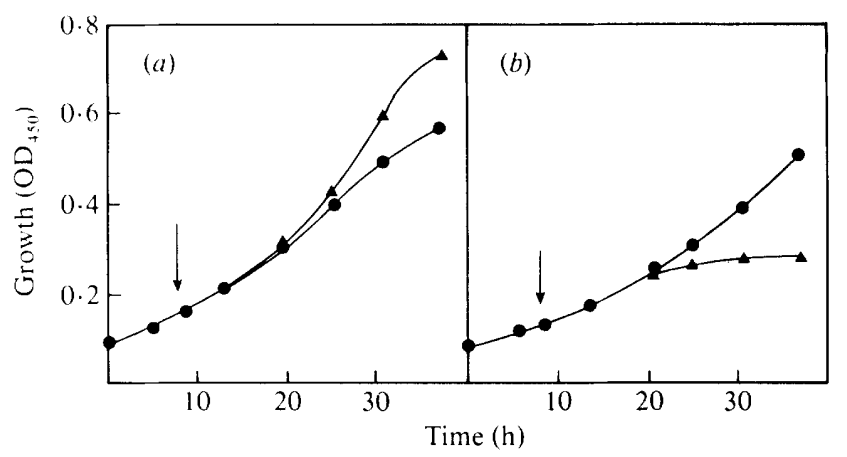

Fig. 2. Effect of 2-chloroethanol on growth of $X$. autotrophicus with methanol. Cells of strain GJ10 (a) and mutant GJ10M41 (b) were grown in batch culture with methanol as the carbon source. At the time indicated by the arrows the cultures were divided in two parts and to one of these $1 \mathrm{mM}$-2-chloroethanol was added. Growth was followed at $450 \mathrm{~nm}$. $\mathbf{\Delta}$, 2-Chloroethanol added; $\mathbf{O}$, control.

Table 4. Enzyme levels in different strains of Xanthobacter

Enzyme activities were determined in extracts prepared from ethanol-grown cells.

$\begin{array}{lcccc}\text { Strain } & \begin{array}{c}\left.\text { S-Decific activity [mU (mg protein) }{ }^{-1}\right] \\ \text { dehalogenase }\end{array} & \begin{array}{c}\text { 2-Chloroethanol } \\ \text { dehydrogenase }\end{array} & \begin{array}{c}\text { Chloroacetaldehyde } \\ \text { dehydrogenase }\end{array} & \begin{array}{c}\text { Chloroacetate } \\ \text { dehalogenase }\end{array} \\ \text { GJ10 } & 232 & 330 & 174 & 416 \\ \text { GZ29 } & <5 & 930 & 155 & <5 \\ \text { 7C } & <5 & 804 & 184 & <5 \\ \text { XD } & <5 & 748 & 171 & <5\end{array}$

ethanol, $X$. autotrophicus strains GZ29, 7C and XD produced 2-chloroethanol and chloroacetaldehyde dehydrogenases at similar levels as strains GJ10 (Table 4). The three strains did not produce 1,2-dichloroethane dehalogenase or chloroacetate dehalogenase, indicating that only the dehydrogenases should be considered as general enzymes of $X$. autotrophicus.

\section{DISCUSSION}

The results presented in this paper demonstrate that the oxidation of 2-chloroethanol to chloroacetate in $X$. autotrophicus GJ10 is catalysed by two different dehydrogenases. The chloroethanol dehydrogenase appeared to be a PQQ-containing alcohol dehydrogenase that due to its broad substrate specificity was active with 2-chloroethanol. Quinoprotein alcohol dehydrogenases have been identified in several methylotrophic bacteria (Anthony, 1982; Duine \& Frank, 1981a). The enzymes require ammonia or amines for activity and catalyse the oxidation of several primary alcohols. It has been shown that 2-chloroethanol can be a substrate for these enzymes (Anthony \& Zatman, 1967; Beardmore-Gray et al., 1983).

The quinoprotein alcohol dehydrogenase of $X$. autotrophicus GJ10 was found to be a $60 \mathrm{kDa}$ polypeptide with which a $10 \mathrm{kDa}$ protein was associated. A subunit molecular mass of $60 \mathrm{kDa}$ has been found for several other dye-linked alcohol dehydrogenases (Anthony, 1982; Schär et al., 1985). Recently, Weaver \& Lidstrom (1985) observed simultaneous induction of $60 \mathrm{kDa}$ and $10 \mathrm{kDa}$ polypeptides in Xanthobacter H4-14 during growth on methanol, and they suggested that the $10 \mathrm{kDa}$ polypeptide could be a cytochrome $c_{\mathrm{H}}$. Together with cytochrome $c_{\mathrm{L}}$, this protein is involved in electron transport from the dehydrogenase to cytochrome oxidase during oxidation of methanol (Beardmore-Gray et al., 1983). However, from the absorption spectrum of the purified dehydrogenase, we conclude that the $10 \mathrm{kDa}$ protein found here has lost its haem group or is not a cytochrome. 
The molecular mass of undenatured alcohol dehydrogenase was $66 \mathrm{kDa}$ or $120 \mathrm{kDa}$ depending on the composition of the buffer used for gel filtration. Thus, subunit composition is a poor criterion for the classification of quinoprotein dehydrogenases. Regarding substrate specificity, the alcohol dehydrogenase of $X$. autotrophicus GJ 10 strongly resembles the methanol dehydrogenase of Methylophilus methylotrophus (Beardmore-Gray et al., 1983), Methylomonas methanica (Patel et al., 1978) and Methylosinus sporium (Patel \& Felix, 1976). The enzyme described here is similar to these proteins in having a high isoelectric $\mathrm{pH}$, as indicated by its lack of binding to DEAE-cellulose at $\mathrm{pH} 7.5$.

Formaldehyde was a good substrate for the alcohol dehydrogenase. The oxidation of this compound is assumed to be the result of hydration to the gem-diol (Sperl et al., 1974). Acetaldehyde and higher aldehydes (up to $\mathrm{C}_{4}$ ) are not substrates for the enzyme, although they are also highly hydrated in water. This can be explained by assuming the presence of two different catalytic sites on the enzyme (Duine \& Frank, 1981 a; Schär et al., 1985). On the other hand, there seems to be a correlation between enzyme activity with higher aldehydes and activity with secondary alcohols. The alcohol dehydrogenase from Rhodopseudomonas acidophila (Sahm et al., 1976; Yamanaka \& Minoshima, 1984), Hyphomicrobium MS223 (Schär et al., 1985) and an unidentified Gram-negative bacterium (Duine \& Frank, 1981b) are exceptional in that they show activity with secondary alcohols. For these enzymes, $\mathrm{C}_{2}$ to $\mathrm{C}_{4}$ aldehydes are also substrates. Thus, an alternative explanation is that the lack of oxidation of both higher aldehydes and of secondary alcohols is caused by steric hindrance, since unlike primary alcohols and formaldehyde, these compounds have two bulky groups bound to the same carbon atom as the hydroxyl group of the substrate.

Radiochemical labelling and experiments with spheroplasts have suggested that the PQQdependent alcohol dehydrogenase of methylotrophic bacteria is a periplasmic enzyme (Kasprzak \& Steenkamp, 1983; Alefounder \& Ferguson, 1981). The soluble 1,2-dichloroethane dehalogenase of $X$. autotrophicus GJ10 seems to be a cytoplasmic enzyme, as suggested by the presence of $N$-formylmethionine at the amino terminus (Keuning et al., 1985). The above would imply that during growth with 1,2-dichloroethane the substrate is taken up into the cytoplasm to become dehalogenated to 2-chloroethanol, which is subsequently exported to the periplasm to undergo conversion to chloroacetaldehyde, followed by re-uptake and further metabolism in the cytoplasm. In accordance with this, we observed that 2-chloroethanol may transiently accumulate in the medium during growth of strain GJ10 with 1,2-dichloroethane in batch culture (up to $0.5 \mu \mathrm{M}$-2-chloroethanol with $5 \mathrm{~mm}$ substrate; details not given).

The second dehydrogenase that plays a role in 1,2-dichloroethane and 2-chloroethanol utilization appeared to be an inducible NAD-dependent chloroacetaldehyde dehydrogenase. Its involvement in 2-chloroethanol metabolism was evident from the observation that the enzyme was lacking in a mutant that could not grow with 1,2-dichloroethane or 2-chloroethanol, but that still utilized glycolate. The enzyme is also involved in the metabolism of the natural compound ethanol, as shown by the extremely slow growth of the mutant when this alcohol was provided as sole carbon source. NAD-dependent chloroacetaldehyde dehydrogenase has previously been demonstrated in a 1,2-dichloroethane utilizing bacterium that was assumed to degrade 1,2dichloroethane directly to chloroacetaldehyde by an oxidative reaction (Stucki et al., 1983).

The evolutionary development of catabolic routes for the degradation of anthropogenic compounds is an intriguing problem. Here, we have shown that the chloroethanol dehydrogenase and the chloroacetaldehyde dehydrogenase produced by $X$. autotrophicus GJ10 for the metabolism of 1,2-dichloroethane should be considered as normal proteins with a function in the metabolism of the natural compounds methanol (and other primary alcohols) and ethanol, respectively. Both enzymes seem to be generally present in Xanthobacter, including strains that do not utilize chlorinated substrates, and fortuitously play a role in the metabolism of xenobiotic compounds due to their broad substrate specificity. The additional ability to produce two constitutive dehalogenases allows strain GJ10 to utilize chlorinated substrates. Whether these dehalogenases are encoded by some transmissible genetic elements remains to be determined. 
The authors thank Professor Duine, Technical University of Delft, for confirming the presence of PQQ in purified alcohol dehydrogenase, and Professor H. G. Schlegel, University of Göttingen as well as Dr L. Dijkhuizen for a gift of bacterial strains. Thanks are due to Ine Bont for typing the manuscript. This work was financed in part by the Netherlands Programme Commission for Biotechnology.

\section{REFERENCES}

Alefounder, P. R. \& Ferguson, S. J. (1981). A periplasmic location for methanol dehydrogenase from Paracoccus denitrificans: implications for proton pumping by cytochrome $a a_{3}$. Biochemical and Biophysical Research Communications 98, 778-784.

ANTHONY, C. (1982). The Biochemistry of Methylotrophs. London: Academic Press.

ANTHONY, C. \& ZatMAN, L. J. (1967). The microbial oxidation of methanol. Purification and properties of the alcohol dehydrogenase of Pseudomonas sp. M27. Biochemical Journal 104, 953-959.

BeARdsmore-Gray, M., O'KeEFE, D. T. \& ANTHONY, C. (1983). The methanol : cytochrome $c$ oxidoreductase of methylotrophs. Journal of General Microbiology 129, 923-933.

Duine, J. A. \& FranK, J. (1981a). Methanol dehydrogenase: a quinoprotein. In Microbial Growth in $C_{1}$ Compounds, pp. 31-41. Edited by H. Dalton. London: Heyden.

DUINe, J. A. \& Frank, J. (1981 $b$ ). Quinoprotein alcohol dehydrogenase from a non-methylotroph, Acinetobacter calcoaceticus. Journal of General Microbiology 122, 201-209.

JansSen, D. B., Scheper, A. \& Witholt, B. (1984). Biodegradation of 2-chloroethanol and 1,2-dichloroethane by pure bacterial cultures. In Innovations in Biotechnology, pp. 169-178. Edited by E. H. Houwink \& R. R. van der Meer. Amsterdam: Elsevier.

Janssen, D. B., Scheper, A., Dijkhuizen, L. \& Witholt, B. (1985). Degradation of halogenated aliphatic compounds by Xanthobacter autotrophicus GJ10. Applied and Environmental Microbiology 49, 673-677.

Kasprzak, A. A. \& Steenkamp, D. J. (1983). Localization of the major dehydrogenases in two methylotrophs by radiochemical labeling. Journal of Bacteriology 156, 348-353.

Keuning, S., Janssen, D. B. \& Witholt, B. (1985). Purification and characterization of hydrolytic haloalkane dehalogenase from Xanthobacter autotrophicus GJ10. Journal of Bacteriology 163, 635-639.

LAEMMLI, U. K. (1970). Cleavage of structural proteins during assembly of the head of bacteriophage T4. Nature, London 227, 680-685.

Patel, R. N. \& Felix, A. (1976). Microbial oxidation of methane and methanol: crystallization and pro- perties of methanol dehydrogenase from Methylosinus sporium. Journal of Bacteriology 128, 413-424.

Patel, R. N., Hou, C. T. \& Felix, A. (1978). Microbial oxidation of methane and methanol: crystallization of methanol dehydrogenase and properties of holo- and apo-methanol dehydrogenase from Methylomonas methanica. Journal of Bacterio$\log y$ 133, 641-649.

SaHM, H., Cox, R. B. \& Quayle, J. R. (1976). Metabolism of methanol by Rhodopseudomonas acidophila. Journal of General Microbiology 94, 313322.

Schär, H.-P., Chemla, P. \& Ghisalba, O. (1985). Methanol dehydrogenase from Hyphomicrobium MS223. FEMS Microbiology Letters 26, 117-122.

SPERL, G. T., ForRest, H. S. \& GibSON, D. T. (1974). Substrate specificity of the purified primary alcohol dehydrogenases from methanol-oxidizing bacteria. Journal of Bacteriology 18, 541-550.

Stucki, G., Krebser, U. \& Leisinger, T. (1983). Bacterial growth on 1,2-dichloroethane. Experientia 39, 1271-1273.

Tunall, N. \& Schlegel, H. G. (1974). A new coryneform hydrogen bacterium: Corynebacterium autotrophicum strain 7C. I. Characterization of the wild type strain. Archives of Microbiology 100, 341350 .

Weaver, C. A. \& Lidstrom, M. E. (1985). Methanol dissimilation in Xanthobacter H4-14: activities, induction and comparison to Pseudomonas AMI and Paracoccus denitrificans. Journal of General Microbiology 131, 2183-2197.

Wiegel, J., Wilke, D., Baumgarten, J., Opitz, R. \& SCHLEGEL, H. G. (1978). Transfer of the nitrogenfixing hydrogen bacterium Corynebacterium autotrophicum Baumgarten et al. to Xanthobacter gen. nov. International Journal of Systematic Bacteriology 28, 573-581.

Wilke, D. \& Schlegel, H. G. (1979). A defective generalized transducing bacteriophage in Xanthobacter autotrophicus GZ29. Journal of General Microbiology 115, 403-410.

YamanaKa, K. \& Minoshima, R. (1984). Comparison of two dye-linked alcohol dehydrogenases of Rhodopseudomonas acidophila: their substrate specificity and behavior toward oxygen. Agricultural and Biological Chemistry 48, 171-179. 